
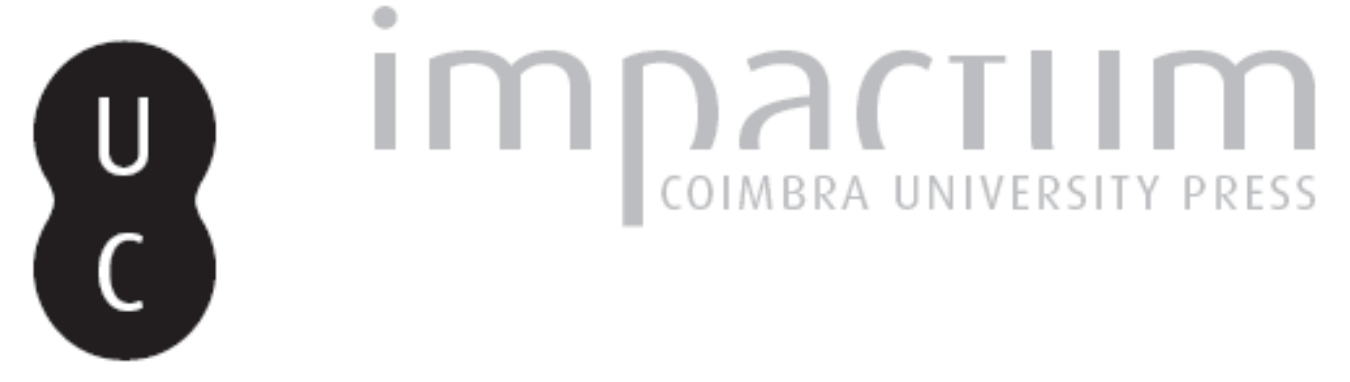

\title{
'Philosophy' in Plato's Phaedrus
}

\section{Autor(es): $\quad$ Moore, Christopher}

Publicado por: $\begin{aligned} & \text { Sociedade Internacional de Platonistas; Imprensa da Universidade de } \\ & \text { Coimbra }\end{aligned}$

URL

persistente:

URI:http://hdl.handle.net/10316.2/38747

DOI:

DOI:http://dx.doi.org/10.14195/2183-4105_15_4

Accessed : $\quad$ 26-Apr-2023 13:50:16

A navegação consulta e descarregamento dos títulos inseridos nas Bibliotecas Digitais UC Digitalis, UC Pombalina e UC Impactum, pressupõem a aceitação plena e sem reservas dos Termos e Condições de Uso destas Bibliotecas Digitais, disponíveis em https://digitalis.uc.pt/pt-pt/termos.

Conforme exposto nos referidos Termos e Condições de Uso, o descarregamento de títulos de acesso restrito requer uma licença válida de autorização devendo o utilizador aceder ao(s) documento(s) a partir de um endereço de IP da instituição detentora da supramencionada licença.

Ao utilizador é apenas permitido o descarregamento para uso pessoal, pelo que o emprego do(s) título(s) descarregado(s) para outro fim, designadamente comercial, carece de autorização do respetivo autor ou editor da obra.

Na medida em que todas as obras da UC Digitalis se encontram protegidas pelo Código do Direito de Autor e Direitos Conexos e demais legislação aplicável, toda a cópia, parcial ou total, deste documento, nos casos em que é legalmente admitida, deverá conter ou fazer-se acompanhar por este aviso.

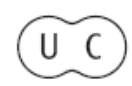


0

\section{Established 1989}

$\infty$ http://platosociety.org/

\section{Papers}

Thomas C. Brickhouse

Nicholas D. Smith

Socrates on the Emotions

Yosef Z. Liebersohn

Socrates, wake up! An analysis and exegesis of the "preface" in Plato's Crito (43a1-b9)

Nathalie Nercam

L'introduction problématique du Timée (17a-27a)

Christopher Moore

'Philosophy' in Plato's Phaedrus

Laura Candiotto

Plato's cosmological medicine in the discourse of Eryximachus in the Symposium. The responsibility of a harmonic technê

Anthony Hooper

Scaling the Ladder

Why the Final Step of the Lover's Ascent is a Generalizing Step

$\varangle$

Z
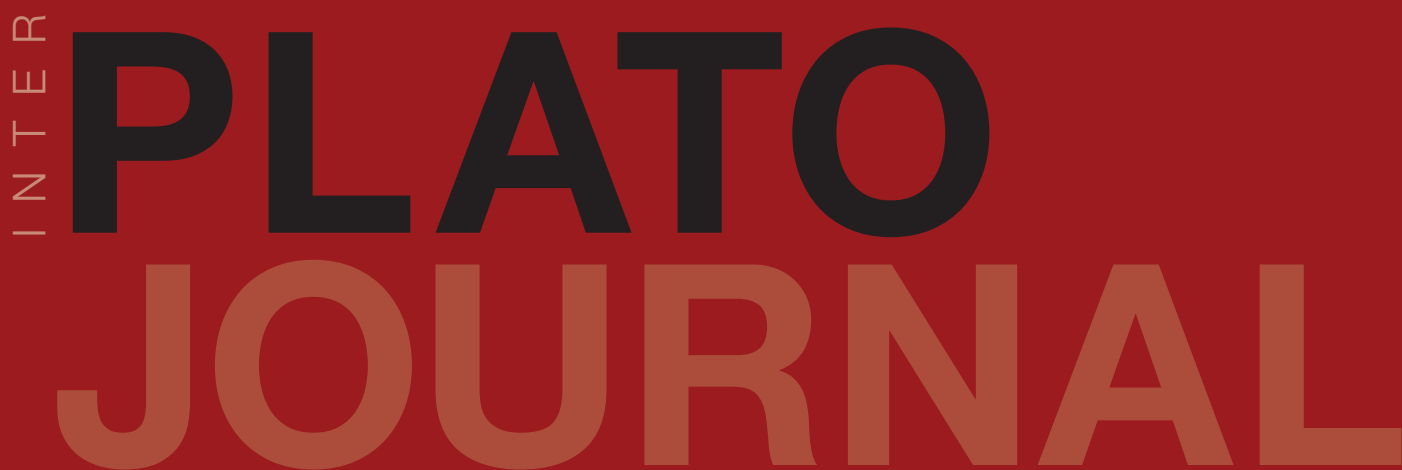

Société Platonicienne Internationale

Associazione Internazionale dei Platonisti

Sociedad Internacional de Platonistas

Internationale

Platon-Gesellschaft

Imprensa da

Universidade

de Coimbra

Coimbra

Universiy

Press 


\section{'Philosophy' in Plato's Phaedrus}

\section{Christopher Moore}

The Pennsylvania State University

c.moore@psu.edu

\section{ABSTRACT}

The Phaedrus depicts the Platonic Socrates' most explicit exhortation to 'philosophy'. The dialogue thereby reveals something of his idea of its nature. Unfortunately, what it reveals has been obscured by two habits in the scholarship: (i) to ignore the remarks Socrates makes about 'philosophy' that do not arise in the 'Palinode'; and (ii) to treat many of those remarks as parodies of Isocrates' competing definition of the term. I remove these obscurities by addressing all fourteen remarks about 'philosophy' and by showing that for none do we have reason to attribute to them Isocratean meaning. We thereby learn that 'philosophy' does not refer essentially to contemplation of the forms but to conversation concerned with selfimprovement and the pursuit of truth.

Keywords : Socrates, philosophia, conversation, self-improvement, Charmides, Protagoras. 


\section{INTRODUCTION}

This paper concerns the way Plato presents what he terms 'philosophy' (philosophia). I argue that we have reason to reassess the Republic-inspired view that Plato believes philosophy simply to be contemplation of the forms. In many dialogues, he treats philosophy instead as a self- and other-improving mode of conversation and social engagement. Platonic forms may of course give a possible metaphysical or epistemological explanation for the benefit of such conversations. But this is consistent with the term 'philosophy' pertaining directly to an interpersonal practice concerned with mutual self-improvement. In this paper I can go only a short ways in reconsidering Plato's attitudes toward 'philosophy'. Yet Plato's importance to the early definition of philosophy is so profound that I hope even this small contribution is valuable. ${ }^{1}$

Plato's Phaedrus ends in a reflection on the meaning and application of the term 'philosopher'. Socrates tells Phaedrus to report to his dear Lysias the findings of the conversation depicted over the previous fifty Stephanus pages. Whoever can compose speeches knowing the truth, and then defend those speeches and show their minimal worth, Socrates says, we should call "'philosopher", or something like that'

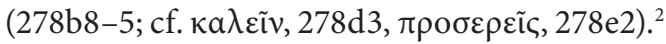
Socrates suggests that Lysias the speechwriter does not yet deserve to be called by that name ( $\dot{\pi} \pi v v \mu i \alpha$ ) but that Phaedrus should himself strive to deserve it. In response to Socrates' judgment about his favorite, Phaedrus asks Socrates what kind of person they might call his

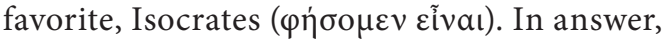
Socrates praises Isocrates as by nature better than Lysias in speeches ( $\lambda$ ójouc), as more nobly blended in character, and as more promising than anyone now alive (279a3-7). Socrates adds that there is by nature within Isocrates' mind

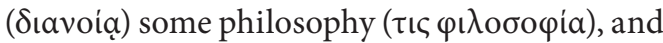
because of this, a more-divine impulse could lead him to better things, if he should want so to be led.

In the course of the conversation with Phaedrus that leads up to these closing remarks, Socrates has already said much about the meaning of the name 'philosopher' that is to be relayed to Lysias. His mythical Palinode speech linked philosophers with truth-discovery, and he later outlined an argument that assumed that philosophizing involves knowing how things really are, not just how they seem to be (261a3-262c4). Socrates' discussion of reading, and his continued request for answers and revised answers, shows the importance of defending one's views (275d4-276a7). His doubt that he could ever give a proper account of the soul, or of himself, suggests that human existence calls for deep modesty and reserve (246a4-6, 266b3-c1).

We might wonder, however, about the philosophia mentioned in the dialogue's closing lines as being by nature within Isocrates' mind. Does it refer to the same philosophy that Socrates wants Phaedrus to recommend to Lysias, which includes investigating reality, giving reasoned arguments in support of one's positions, and recognizing the meagerness of any written account? From one perspective, it seems it must. Socrates never posits a multiplicity of types of philosophy. Further, the proximity between the two remarks about philosophy suggest continuity in meaning between them. And even if it simply seems too ludicrous to identify Isocrates with philosophy, Socrates does not say that Isocrates exemplifies philosophy; he says only that Isocrates has tina philosophian, 'some' or 'a kind of' philosophy. ${ }^{3}$

From another perspective, however, it might seem that Isocrates' philosophia must 
differ from the kind that Socrates encourages Phaedrus to acquire. We might expect Isocrates' profession of rhetoric to appear anathema to Socrates and Plato. After all, Socrates distinguishes sharply between popular rhetorical training and the training he recommends for Phaedrus. Isocrates' extant speeches show that he often used the term philosophia, in particular in contexts where Isocrates deliberately contrasted his practice with the overwrought and captious arguments of the Socratics and Aristotelians. ${ }^{4}$ It seems likely that Isocrates and Plato, perhaps among others, competed for students, in part by showing those students the ideal and realistic targets of their respective forms of philosophia. ${ }^{5}$ Indeed, most readers now simply assume without argument that Isocrates'

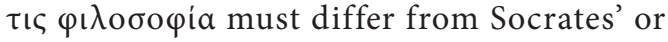
Plato's. G.J. De Vries says that Socrates refers to Isocrates with 'mordant sarcasm' and that 'Plato leaves it to his readers to decide whether

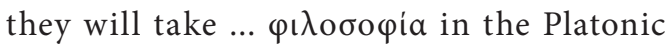
or the Isocratic sense'. ${ }^{6}$ Harvey Yunis says that the $\tau ı \varsigma$ 'suggests that Isocrates occupies an ambiguous position between the (conventional) philosophia that he promotes (239b4n.) and the (true Platonic) philosophia that remains for him an as yet unrealized possibility'. Yunis expresses the difference between these two types of philosophia by appeal to the difference between rhetoric and philosophy mentioned at the end of the Palinode (257b4). ${ }^{7}$ Daniel Werner claims that it is likely that

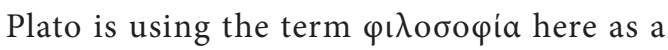
way of taunting Isocrates, and is deliberately leaving it ambiguous as to which sense of the term is meant'. ${ }^{8}$ All agree that Isocrates' philosophy is a conventional form of philosophy aligned with rhetorical culture; Plato's philosophy is an innovation, concerned with the contemplation of the really real. ${ }^{9}$
There are therefore reasons both for accepting and for rejecting the idea that Plato uses a single idea of 'philosophy' on the final page of the Phaedrus, and by extension, in the dialogue as a whole. Whether we should accept or reject the idea matters a lot, though, and for more than unearthing Plato's attitude toward Isocrates..$^{10}$ In this dialogue more than almost any other, Socrates expresses his hopes that his interlocutor might turn to 'philosophy'." As the Palinode ends, Socrates tells Phaedrus to settle on one way of life and to give himself 'wholly over to love accompanied by philosophical talk' (257b6). Two pages later, Socrates warns Phaedrus that the cicadas singing overhead tell the muses which humans spend time in philosophy and which in sheep-like sleep (259b3). Again two pages later, Socrates tells some logoi to persuade Phaedrus that lest he practice philosophy well, he will never be able to speak well (261a4). To what then does Socrates encourage Phaedrus? Unfortunately, Socrates never explicitly and completely defines philosophia, the philosophos, or the activity of philosophein. The circumstantial evidence appears to vary broadly in the images of philosophy he gives. 'Philosophy' is presented as a kind of association, a trait of character, a way of life, a cognitive activity, a direction of research, and an attitude of valuation. Given this variety and the importance of the question, it is remarkable that readers have simply divided the references to philosophy into two groups, Platonic and non Platonic, indeed without any clear criterion of division. More troublingly, dismissing as merely 'conventional' the purportedly non Platonic uses - the ones that do not focus on contemplating an unchanging reality - limits our understanding Socrates' actions in urging Phaedrus to adopt a 'philosophical' life.

This paper reconsiders the nature of philosophia in the Phaedrus. As a preliminary, 
I study the uses of 'philosophy' group words in two other Platonic dialogues: the Charmides and the Protagoras. Against this background, I assess in turn each appearance of the word group in the Phaedrus. Proceeding in order of appearance lessens the chance of selective defense of one view of philosophy or another. It also reveals the inadequacy of apportioning those appearances between two starkly contrasting senses.

\section{II. 'PHILOSOPHY' IN THE WORLD OF PLATO'S SOCRATES}

\section{THE CHARMIDES}

The Charmides depicts Socrates narrating to his unnamed friend his return from Potidaea, in 429. He went immediately, he says, to his discussion-circle of friends and recent additions, comprising Chaerephon, Critias, and a large group of others ( $\pi \dot{\alpha} v v \pi 0 \lambda \lambda$ ov́ $\varsigma$, 153a5). He answered questions about his military campaign, he says, and then asked his own questions. He wondered about the contemporary state of 'philosophy' ( $\pi \varepsilon \rho \mathrm{i}$

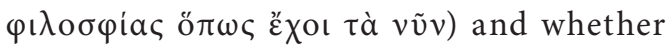
any young men had distinguished themselves in wisdom, beauty, or both $(153 \mathrm{~d} 2-4) .{ }^{12}$ As soon as he poses his questions, however, Charmides' followers enter the room. The conversation turns to Charmides, pushing Socrates' question about philosophy aside. 'Philosophy' arises explicitly only once again, a short while later in a scene Socrates reports in direct speech.

Critias and Chaerephon describe Charmides to Socrates. With Charmides before them, they agree that he has a beautiful face. Socrates is told that, beneath his robes, he has a completely beautiful body. Socrates thinks that such physical beauty would be worth noting only if Charmides' soul also happens to be well developed ( $\varepsilon \tilde{v} \pi \varepsilon \varphi v \kappa \omega \varsigma$ ). He could evaluate this by having Charmides bare his soul and letting them look at it. 'For', Socrates says, 'I suppose he is quite of the age to be willing to converse' ( $\dot{\varepsilon} \theta \dot{\varepsilon} \lambda \varepsilon \iota \delta\llcorner\alpha \lambda \dot{\varepsilon} \gamma \varepsilon \sigma \theta a \mathrm{l})$. Critias heartily agrees (кaì $\pi \dot{\alpha} v v \gamma \varepsilon$ ), 'since he is, you know, a philosopher and also, so it seems to others as well as to me, quite a poet'. Critias' affirmation means that he thinks, and thinks that Socrates agrees, that being a philosopher means being able to converse in a way that would reveal the nature of one's soul. As the conversation proceeds, we find that Charmides really does have some important conversational abilities. Most notably, Charmides knows to answer definitional questions 'in a word' (159b5, 160e4-5), in the Socratic fashion featured in the Meno, Euthyphro, and Laches.

If we survey together the dialogue's two uses of 'philosophy' group words, we can see that 'philosophy', at least in the Charmides, means having certain kinds of conversations among those practiced, accustomed, and intentionally engaged in doing so, conversations that come to reveal the quality of one's soul - including, presumably, its wisdom and beauty. On the likely assumption that the conversation depicted in the dialogue follows the pattern of conversations Socrates, Critias, Chaerephon, and the rest had in the years before Socrates' departure to Potidaea, this conversation exemplifies philosophical conversation. Since the conversation with Charmides and Critias works to assess these men's attitudes toward, understanding, and personal manifestation of sôphrosunê, such assessment would be central to philosophy. 


\section{THE PROTAGORAS}

In the Protagoras, the conversation between Protagoras and Socrates falters when Socrates charges the sophist with talking at too great a length (here, about the relativity of goodness, 334a1-335a7); such speeches, he claims, exceed his comprehension. So Socrates states that he will simply have to leave the party. His companions, aghast, broker a peace treaty: Protagoras will take a turn asking Socrates whatever he wishes. Protagoras chooses to ask about a song by Simonides. Socrates starts his interpretation with some abortive appeals to Prodicean synonyms. For his new approach, he will explain the song's rhetorical situation. This approach requires that he give background information about the competitive use of gnomic phrases, relevant in this case to Simonides' takedown of Pittacus' maxim, 'Hard it is to be good'. Socrates introduces his background digression with a remark about philosophy: 'Philosophy is most ancient and most plentiful among the Greeks in Crete and in Sparta, and the most sophists on earth are there' (342b8). This is a baffling remark. Fortunately, there are a few things to go on. Socrates had mentioned 'philosophy' not long before. After Socrates made to leave Callias' house, his host begged Socrates not to abandon the conversation. Socrates, in response, claimed that he always admired (ä $\gamma \alpha \mu a \mathrm{l}) \mathrm{Cal}$ lias' 'philosophy' (335d10). Socrates also ends up mentioning 'philosophy' some lines after his first claim about Crete and Sparta. He says that the Spartans 'have been educated best in philosophy and speeches' (342d7-8). So, in the remark about Callias, 'philosophy' must refer to a commitment to the kind of ordered talking about significant matters - for instance, about virtue and goodness - exemplified by the conversation between Socrates and Protagoras, and presumably arranged on more than this occasion by Callias. ${ }^{13}$ Since the conversation between Socrates and Protagoras has oscillated between cooperative and competitive engagement, we cannot tell whether either form typifies 'philosophy' as Socrates' contemporaries, or Socrates himself, understands the word. In the latter remark, 'philosophy' is related to speeches in the context of excellent education. The best education, it might seem, would get people to talk best about the best topics. From these sandwiching uses of 'philosophy', Socrates seems to be opening his explanation of Simonides' song by saying that the Cretans and Spartans have had the longest and largest commitment to talking about significant matters, virtue and goodness included. ${ }^{14}$ We cannot tell, however, whether an 'education in philosophy and speeches' has at its focus constructive or agonistic engagement; probably the ambiguity is deliberate. ${ }^{15}$

As both the Protagoras and the Charmides show, Socrates uses the term 'philosophy' to refer to conversations that follow certain norms of productive engagement and that concern virtues and the possession or transmission of them. These conversations appear to include sequential and hard-pressing questions about definitions and about identities between similar concepts. They may also include explanations of one's views, interpretations of sayings and texts, and presentations of various forms with subsequent discussion of those presentations. 


\section{FOURTEEN OCCURRENCES OF 'PHILOSOPHY'-GROUP WORDS IN THE PHAEDRUS}

\section{AN ASSOCIATION FOR BECOMING MOST THOUGHTFUL}

The first occurrence of 'philosophy' in the Phaedrus is found in Socrates' first speech. In this speech, Socrates argues from the perspective of a putative non-lover, as Lysias did, that a young man should spend time with him, not with someone actually in love with him. Socrates' speech differs from Lysias', which feigned extemporaneity and argued from endoxa, in its appeal to a materialist psychology, one that places the inevitability of love's corruption in the necessary causal forces of a person's body or mind. Among the reasons Socrates gives in this speech against spending time with a lover is the following:

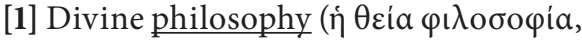
$239 \mathrm{~b} 4$ ) is a kind of association ( $\sigma v v o v \sigma \iota \tilde{\omega} v$ ) aimed at making one most thoughtful

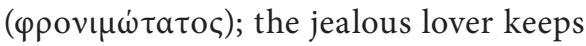
his beloved away from such beneficial $(\dot{\omega} \varphi \varepsilon \lambda i \mu \omega v)$ associations, just as he does from those that could make someone most a man ( $\mu \alpha \dot{\lambda} \lambda \iota \sigma \tau^{\prime}$ à $\left.v \dot{\eta} \rho\right)$ : stronger, wiser ( $\sigma \circ \varphi \circ \tilde{)})$, braver, more eloquent

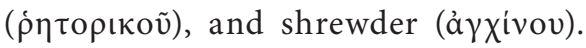
(239a2-b8, paraphrased)

As a goal-directed social arrangement, this philosophia parallels the philosophia in the Charmides and Protagoras. Whereas other associations help people come into their maturity through work on strength, skill and experience, courage, the ability to speak well publicly, and cleverness, this association helps people become more thoughtful, reasonable, and insightful. It is a beneficial and distinctive sort of group. A person participating in it may seem to leave his other putative relationships and obligations behind, as the jealous lover fears (cf. 252a1-b1). This must be because it nurtures a sense of useful and enjoyable community. It seems to be the sort of community we see formed around Socrates in other Platonic dialogues.

Despite the close similarity between Socrates' use of the word philosophia here and his uses in other dialogues, commentators have been skeptical about his intentions. Some skepticism about the content of Socrates' speech may be warranted; Socrates disclaims true authorship of it (235b7-d3, 238c5-d5, 241e1-5, 242b4), and even later disowns it (242d4-e1, 243c1-2, d3-5), on the grounds that it did not venerate love adequately. All the same, disclaiming or disowning a speech does not mean that every claim in it opposes the speaker's beliefs, every word used in a way other than the way the speaker would. Surely jealous lovers really would prevent their beloveds from spending time among such groups of friends engaged in philosophy. And even if jealous lovers did allow their beloveds time away from them, Socrates says nothing to discount the plausibility of his description of philosophy.

Recent skepticism about this remark about philosophia focuses on Isocrates. ${ }^{16}$ Yunis, for example, says that Socrates uses the term here 'without content and in support of conventional values' ${ }^{17}$ In doing so, Yunis says, Socrates' remark has 'an Isocratean resonance'. Yet Yunis seems mistaken. Socrates' use does not lack content. Socrates speaks of philosophia as a 'beneficial' 'being-together' that makes one 'most thoughtful' on the way to becoming 'most a man'. It is true that Socrates does not adumbrate here the sorts of conversations or activities a philosophical association engages in, but he did not do so in the other dialogues 
we have looked at either, and yet the content of philosophy there was perfectly clear. More importantly, it is possible that no specific methodological procedures - such as analysis, deduction, or concept-definition - are necessary features of philosophical practice. It is also not evident that Socrates appeals only to 'conventional values' in lauding 'divine philosophy'. He does, admittedly, put philosophia in line with - though possibly also in contrast with - gymnastics, studies, martial training, rhetorical training, and cleverness, presumably conventional values. But if becoming 'most thoughtful' is itself conventional, then it is hard to assess the critical purchase of Yunis' derogatory remark.

Even Yunis recognizes, however, that his bifurcation between Isocratean and Socratic-Platonic philosophy is problematic. 'Plato also undercuts that [Isocratean] sense [... with his] emphasis on the extraordinary value of philosophia - its absence constitutes the greatest harm to the erômenos - and the epithet "divine"'. Of course Isocrates also thought philosophy had extraordinary value. In any event, this speech treats philosophia as important in the ways Socrates often suggests it is important. Perhaps Socrates could mean philosophia in two ways simultaneously. But it is simpler and contextually consistent to believe that he means it in only one.

\section{THE ALLIES OF THE PHILOSOPHER}

Instances of the 'philosophy' word-group arise again three pages into the Palinode. Socrates has represented the life of the gods as souls in chariots endlessly circling the world. Mortals, by contrast, circle the world only until

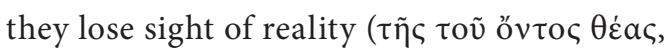
248b4). This means, as the Palinode reiter- ates, that every human soul has in fact seen the realities ( $\tau$ ò ôv $\tau \alpha$ ), difficult as keeping an eye on them may be (249e4-250a3), but that each eventually loses track of the truth, suffering from distraction and badness $(\lambda \dot{\eta} \theta \eta \varsigma . .$. кakiac, 248c7), and falls to the ground. Fortunately, not all is lost; souls are replanted in human lives, each into a person in one of nine ordered classes. Into the premier class go the philosophers:

[2] The [soul] that sees the most [is put] into a seed of a man who will become a philosopher or a philokalos or a dedicatee of culture or of love ( $\varphi$ ı $\lambda$ oбó $\varphi$ ov

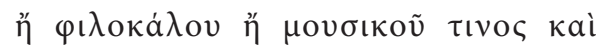

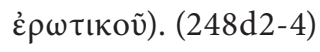

Passage [2] does not emphasize what the instances of 'philosophy' found in Charmides, Protagoras, and passage [1] emphasize, and that [3], below, may allude to, namely, that philosophy is a group conversational and mutually-improving or benefitting practice. It focuses instead on philosophy as a distinct way of life, as something that could define a person's entire course of existence. Along with its focus on philosophy as a way of life is the Palinodes' linking of philosophy with three other types of life: the philokalos, the person of mousikê, and the person of erôtikê. ${ }^{18}$ Frustratingly, it does not explain the relationship between these four (or three) types of life. It does not say whether they are identical, or are instead varieties of the philosophical life, or are, in yet another possibility, distinct species of a common genus of which philosopher is just one species. So to understand the relationship, we must look to the eight lower classes, many of which also have multiple entries.

The second level includes the law-bound king ( $\beta \alpha \sigma \iota \lambda \dot{\varepsilon} \omega \varsigma$ $\dot{\varepsilon} v \nu o ́ \mu o v)$ and the military and 


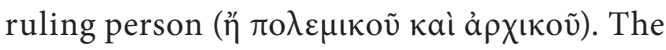
connective structure of the first level suggests that the Palinode is identifying three different kinds of life here. The third level includes the political person ( ple involved in estate-management and busi-

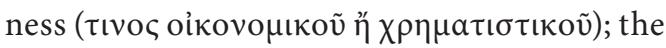
fourth, the hardworking man of the gymna$\operatorname{sium}^{19}$ and the person who knows healing for bodies; the fifth, the mantic and the person concerned with certain rituals; the sixth, the poet and the person concerned with mimêsis; the seventh, the city- and earth-workers; the eighth, the person engaged in sophistry or crowd-rallying; and the ninth, the tyrant (248d4-e3). Socrates explains neither his choice of members for each of the nine levels nor his judgment about the levels' relative position. ${ }^{20}$ All the same, some patterns reveal themselves. Members at the same level obviously differ; the city- and earth-workers (craftsmen and farmers) provide the clearest case. Yet the members at each level also share a general concern: management of a city; management of smaller groups of people; the well-being of the body; religious observance; creation of art; skilled mechanical production of goods and services; and persuasion of people. Tyranny stands alone. The entries in a level mentioned later are not defective, derivative, or secondary forms of the first entry.

This pattern suggests that the four names for lives listed at the first level are not mere synonyms, but different ways of life connected by a general concern. There are no prima facie reasons for thinking the life of the philosophos is being treated as better than or logically prior to the lives of kala, mousikê, or erôtikê. What general concern they share may help us understand the meaning of philosophos here.

Thucydides 2.40.1 most famously links the first two types of life. Written as late as 394 (and thus in the decade or two before the Phaedrus), but set in 431 (in the decade or two before the dramatic date of the Phaedrus), Thucydides' Pericles defends his people, the Athenians, from slander. ${ }^{21}$ 'We philokaloumen with economy, and we philosophoumen without weak-

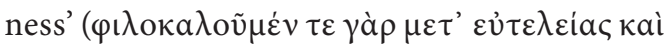
$\varphi \iota \lambda о \sigma o \varphi о \tilde{\mu} \mu \varepsilon v a ̈ v \varepsilon v \mu a \lambda \alpha \kappa i a \varsigma)$. Critics of Athenian hegemony have presumably insulted the Athenians with these names. Pericles suggests that the names are appropriate only if qualified. What exactly Pericles understands the names to mean is difficult to establish, particularly because Thucydides provides the first extant use of the first verb, and among the earliest of the second verb. But Pericles' subsequent sentences gloss his jingly defense:

We use our wealth for timeliness of action more than for boastfulness in speech: it is not shameful for someone to admit to poverty; it is rather more shameful not to flee from it with effort. Some of us apply ourselves both to household and to political matters, while others, having been turned toward work, know political matters perfectly well. We alone consider the man sharing in none of these to be not idle, but useless, and we judge, or even correctly devise affairs, not considering speeches a harm to actions, but rather [considering the real harm to be] not having already learned, through speech, before coming upon what is necessary in terms of action. For indeed we so excel in this as, extraordinarily, both to exercise courage and to reason out whatever we may attempt. And they are rightly judged strongest in soul who know most clearly what is terrible and what is pleasurable and who, on account of this, do not turn away from risks. (2.40.1-3) 
The speech makes quick work of philokaloumen. Obviously linked to wealth already in its qualification with euteleias ('easily concluded', 'easy to pay for', 'frugal'), the immediately following sentence links it literally to wealth ( $\pi \lambda$ ov́ $\tau \omega)$. It seems that 'loving beauty' is actually a sardonic euphemism for 'being extravagant'. Pericles' building programs come immediately to mind. Pericles justifies having and using money on the grounds that it prepares the city for contingencies; it does not simply manifest conspicuous consumption. Indeed, Pericles continues, it is undignified to care neither for money nor for the benefits it conveys. So the name philokalos and action philokaleô refer ostensibly to a person inspired by ornament, grandiosity, and the image of robust health; and yet behind those appearances, Pericles says, is an actual concern for living well in a world where timely action is needed.

Pericles' speech gives more time to the charge that Athenians 'philosophize'. ${ }^{22}$ All Athenian citizens either deal with, or at least know about, political matters; and this commitment to political matters is more a political obligation than a choice. Philosophizing must have something to do with being concerned with or cognizant about politics. In fact, it means using speech to think through and then to decide how to act before the necessity of decision arises. It is not, that is, simply talking about important matters, but talking in preparation for action, in hypothetical terms. These preparatory matters include assessing and getting clear about what is bad and what is good. This preliminary work contributes both to heading into conflict with understanding, and thus courage, and to having the chance to deliberate precisely and rapidly about particular plans.

Pericles presumably pairs the charges of philokalein and philosophein because they result from similar appearances - indulging in building and talking, wasting money and time - and have similar functions, the preparation for all eventualities. Both names may have originally been used bemusedly or even angrily, but Pericles explains the appearances that lead to those names. The Athenians have accumulated adequate resources, both in buildings and in thought.

From this perspective, the Palinode's pairing of the philosophos and the philokalos is unsurprising. Both sorts of people have good practical reasons for acting in ways that seem, to outsiders, to be idle talk or the decadent expansion of one's affairs. It is also unsurprising that the Palinode would mention those dedicated to mousikê and erôtikê in this context. The Phaedo presents Socrates saying that he had repeated dreams telling him to make mousikê $(60 \mathrm{e} 3,7)$. He thought that his philosophia was a kind of mousikê, indeed the greatest kind (61a4). Socrates admits that the standard understanding $(\delta \eta \mu \omega \dot{\delta} \eta)$ of practicing

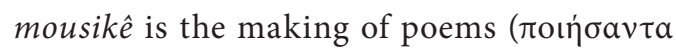

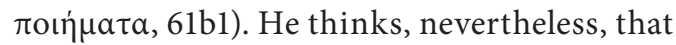
doing philosophy could easily belong to that category. This might seem paradoxical; the Palinode separates the philosophical life from the poetical life by four intermediate lives. In the Phaedo, however, Socrates does not restrict making mousikê to making poems. Mousikê involves some special attitude toward the Muses, that is, toward high culture. Socrates says that he composed a hymn to Apollo, and then versified the stories of Aesop. ${ }^{23}$ The Phaedrus shows that the Muses may be propitiated in still further ways. At the Palinode's beginning, the list of modes of mania includes the mania of the Muses. This mania leads to enrapturing songs and poetry that teach each generation the splendid works of the ancients (245a1-8). After the Palinode, Socrates draws attention 
to the cicadas singing above them. He says that they report to the Muses the people who have properly honored them in dance ( $\dot{\varepsilon} v$ toĩs

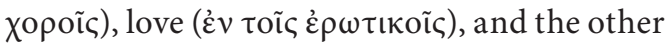
practices (259c5-d3).

As we see, throughout the dialogue, and elsewhere too, Socrates draws complex overlaps between philosophia, philokalia, and the interest in mousikê and erôtikê. The lover of beauty

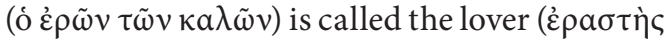
$\kappa a \lambda \varepsilon \tilde{\tau} \tau \alpha)$ when he partakes in mania ( $\mu \varepsilon \tau \dot{\varepsilon} \chi \omega \nu$

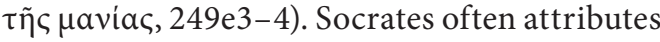
to himself the knowledge of ta erôtikê. ${ }^{24}$ Somehow doing philosophy is similar to doing these other practices, which are themselves similar to each other.

The similarity among the ways of life in the first echelon can be stated in the following way: all four share a certain civic piety, a seriousness of deliberate preparation, concern for conveying cultural norms to later generations, an orientation toward wisdom and its best guise, beauty (250a5-e1), and attention to living well.

For many readers this reading may seem tendentious. After all, the crucial point in [2] is that philosophers have seen the most of 'what is'. Philosophy is to be defined in connection to the really real. In the Palinode, the really real is the set of universals, that which is ascertainable only by mind, for example justice, sôphrosunê, and knowledge themselves (247c5-e2). 'We' followers of Zeus - presumably the philosophers - gaze at the whole, simple, unchanging, blissful revelations, in a pure light (250b7-8). Yet the details of this passage in the Palinode require that we qualify the connection between philosophy and the universals. The philosopher is the person whose soul, in a previous life, saw more than others of 'what is', but who, all the same, failed to keep seeing it. The Palinode does not here set out the nature of the philoso- pher himself; it speaks only about the relative success of the life of the person before he is reincarnated as a philosopher. That it is a matter of relative success informs our understanding of the philosopher. After all, the other lives in the nine-level scale also saw some measure of the really real. Indeed, the philokaloi and dedicatees of culture and love apparently saw the same amount of the really real. So the philosopher cannot be defined solely by his connection to the really real; a positive connection to it exists for everybody else too.

Indeed, as we see from the next passage, the followers of Zeus may not actually be the philosophers alone:

[3] Followers of Zeus look for beloveds who are philosophers and leaders (hêgimonikos) by nature. (252e3)

The 'leaders' - who are perhaps members of the second and third ranks of people - travel with the first rank; and apparently all of these people 'gaze at the whole, simple, unchanging, blissful revelations, in a pure light'. Again, philosophers are not uniquely distinguished by their orientation to the really real.

Thus the Palinode places the philosophers among many others related variably to the reality. But its imagery does not indicate the actions constitutive of those relations. How does one 'philosophize'? The soul, it says, observes the really real; it struggles to stay high in the shared orbit; then it falls to earth. What is the earthly correlate of this observing, and what is the correlate of this contention? I see no way to decide. This interpretative gap means, however, that we cannot simply assume that the human way to seek to know reality is different from any other purportedly non-Platonic method of accessing reality, as long as that method aims to reveal the nature of justice, sound-mindedness, 
and knowledge. Conversation, modeling, apprenticeship, speech-training, and mathematics seem plausible candidates. All that the Palinode suggests, it seems, is that the method of observation and contention practiced by philosophers must share something with the practice of the philokaloi and the dedicatees of culture and love.

\section{PHILOSOPHIZING WITHOUT DECEPTION, AND PEDERASTY WITH PHILOSOPHY}

The Palinode turns now to the career of embodied souls. After their bodies have died, they must wait a long time before returning to the celestial orbit.

[4] The more justly one lives, the better one's lot. For the soul returns to its orbit after ten thousand years, except for the [soul] of the person having philosophized

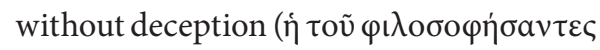
ả $\delta$ ó $\omega \varsigma, 249 \mathrm{a} 1-2)$, in which case it may be a shorter delay.

This remark introduces a longer eschatological discussion, with complexities of judgment and metempsychosis. Relevant for our study is an implication that, if one may philosophize without deception, one may also philosophize with deception. This means that philosophizing has public components. Such public components that could be authentic or deceptive may include being interested in other people, acting with self-discipline, and debating others on important topics. This suggests that private contemplation does not constitute the principal philosophical activity, except insofar as it has an external form for which that contemplation provides justi- fication (as, e.g., Socrates' lateness to a party justified by his solitary reflections [Symp. 174d4-175c7] or his oddness while on campaign [Symp. 220b1-d7]). Otherwise it is hard to see how one could philosophize (internally) with or without deception.

The Palinode goes on immediately to describe another life on the fast-track to re-orbit:

[5] ... or to the one having lived the life of love toward a young man accompanied

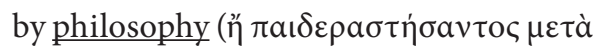

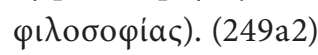

We see a similar formulation at 257b6, [9], below; we will compare them in our discussion there. The disjunction 'ř' seems to distinguish the person philosophizing without deception from the person 'pederasting' with philosophy, but the rest of the dialogue suggests that these two lives coincide. After all, the first two speeches of the dialogue present pederasts who use guile. So if philosophizing without deception is the same as pederasting with philosophy, then philosophy is intrinsically connected to guileless pederasty. This suggests that philosophy is a way of spending time with a young person in order to make him good. This includes making him like his favored god, through persuading and accustoming ( $\pi \varepsilon i \theta o v \tau \varepsilon \varsigma$ kaì $\dot{\rho} v \theta \mu i \zeta o v \tau \varepsilon \varsigma, 252 \mathrm{e} 4-253 c 2)$. Deceptive pederasty is a way of seeming to make the young person good but really caring only for getting favors from him (cf. 227c7).

\section{THE MANIA FOR UNIFYING THE THINGS WE SAY}

The Palinode goes on to describe the conditions for reincarnation as a human. It thereby 
provides what is so far the longest and most complex discussion of the philosopher.

[6] For the [soul] having never seen the truth will never arrive into this shape [of a human]. For a human must comprehend a thing said in accord with a

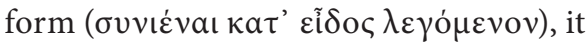
coming from many perceptions into one, being brought together by reasoning ( $\dot{\varepsilon} \kappa$

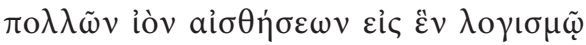

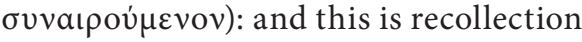
of those things that the soul of us once saw, having accompanied god and looked askance at what we now claim is real, and coming up to what is really real. It is for this reason that the mind ( $\delta$ ióvola) of the philosopher alone becomes winged: for it is always next to these things, by memory, as far as it's able, next to which things god, being divine, is. And indeed, a man using such reminders correctly, being continually initiated into completed mystery rites, alone becomes really completed [i.e., initiated]. And standing outside the realm of things that it is human to take seriously, and becoming next to the divine, he is censured by the many as being deranged, but in fact he is possessed, as escapes the notice of the many. (249b5-d3)

To put it simply, humans collate and abstract, thereby reaching the truth more readily; philosophers distinguish themselves by doing this most consistently. The core idea comes early in the passage. A person must 'comprehend a thing said in accord with a form, it coming from many perceptions into one, being brought together by reasoning' ( $\sigma v v i \varepsilon \dot{\varepsilon} \alpha \mathrm{l} \kappa \alpha \tau$ '

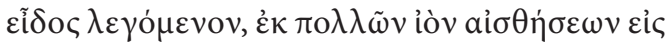

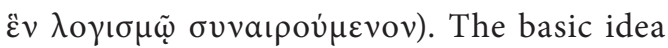
seems straightforward enough: one unifies one's experience through reasoned selection or condensation. ${ }^{25}$ The details are more challenging. To understand (бuvićval) a thing said

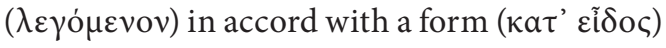
is generally interpreted as meaning something like 'to understand a statement in terms of its reference to a general category of experience, rather than in terms of its reference to concrete particularities'. ${ }^{26}$ But this overinterprets. If the Palinode means to convey any subtle or significant information in the idea kat' eidos, its compressed formulation would be an ineffective way to do so. In particular, it is not clear how a thing said could be understood in accord with anything else other than an eidos (form); after all, understanding kath' idia (particulars), or kata phenomena (appearances), or kata doxa (conventions) seem unpromising routes to understanding. A further difficulty to determinate interpretation comes from the participial phrase following legomenon. It either describes a 'thing said' before it is understood in accord with a form, or glosses a 'thing said' as something once it is so understood. I do not see how to decide on one or the other. All we can say is that the passage describes the process by which individual experiences become something linguistic, and do so only in their unification. The resonance of the Palinode's word-choice suggests this: this 'reasoning' ( $\lambda$ oүı $\sigma \mu \tilde{\omega})$ is like a 'bringing into speech' ( $\lambda \varepsilon \gamma$ ó $\mu \varepsilon v o v)$.

As the Palinode continues in this passage, it describes the philosopher as best fulfilling the human requirement. Like all other humans, the philosopher is engaged with the universals, the things said in accord with form, but unlike non-philosophers he is 'always' engaged with them, to such an extent that he seems bizarre to many people. Of course, as the run-up to passage [2] made clear, the philosopher fails to maintain complete focus on the really real, even if he does not fail as soon as others do. So too 
here, the 'always' is qualified as kata dunamin, 'as far as it [the soul] is able'. The difference is quantitative. Since absolute attendance on the really real is divine - it makes any divine thing (such as gods) divine - all humans share in, or ought to share in, something divine. The philosopher, in seeking to select or bring together perceptions into unifying speeches, shares most in what is most human - being divine.

We should pause to note similarities between [6] and earlier passages. The 'divine philosophy' mentioned at [1] has extra meaning now: philosophy is not just of the deepest importance; it is, as least in this most recent expression, the practice that contributes most directly to being divine. Also in [1], philosophy was said to make one most thoughtful

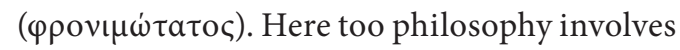
recollecting the most; amplifying understanding, reason, and selective choice; and having a mind (dianoia) most cognizant with the sort of unities typical of divine rationality. Thus Socrates uses the word 'philosophy' in his second speech much the same way he uses it in his first speech. It is worth adding that it may not be so surprising that the philosopher, though really manifesting what is best in humans, seems strange to most humans; as we saw in the discussion of [2], philosophers are grouped with others avid about what is most significant in culture - beauty, art, love - and these people look strange.

\section{PHILOSOPHY AND THE INTEGRATED LIFE}

The Palinode's last two uses of 'philosophy' group words suggest that philosophy is a way of life devoted to proper self-integration. It first addresses the ideal case. Good lovers
[7] strain against [the embraces of the beloved] through shame and speech ( $\mu \varepsilon \tau$ '

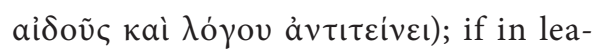
ding to a well-ordered life ( $\tau \varepsilon \tau \alpha \gamma \mu \varepsilon \dot{\varepsilon} \nu \nu$

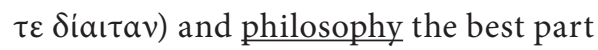
of their mind should prevail, they lead

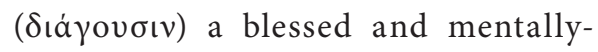

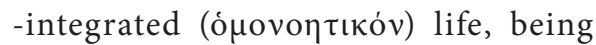
masters of themselves and well-ordered

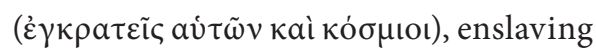
that by which badness enters the soul, and liberating that by which virtue enters. (256a6-b3)

The Palinode then proceeds to the non ideal but not totally unsatisfactory case:

[8] If to a coarser and unphilosophical life

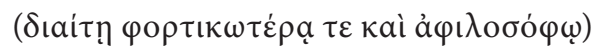
[they turn], and are dedicated to honor ( $\varphi \iota \lambda о \tau i \mu \omega \delta \dot{\varepsilon} \chi \rho \eta \dot{\sigma} \sigma \omega \nu \tau \alpha \iota) . .$. [these people may choose what people call blessed (sc. sex) and] do things not approved by the

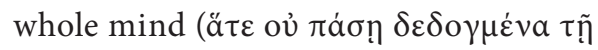

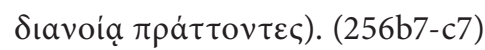

Philosophy is identified in [7] with being well-ordered, directed by reason, self controlled, integrated, and protective of the prerogatives of virtue. There is no reduction of philosophy to a concern for the really real, even if such a concern is, in some way, a condition of philosophy - as it is of any human life. There is repeated emphasis on the virtues organized around sôphrosunê, as we see in the Charmides, the very virtue on which the Phaedrus closes (o $\sigma \dot{\omega} \rho \varphi \omega v, 279 \mathrm{c} 3)$. Passage [8] coordinates philosophy with the absence of coarseness, contrasts it with the concerns for honor and bodily pleasure, reiterates its oddness in the public eye, and treats it as the result of wholehearted attention alone. Just as at the end of the Phae- 
drus, where Socrates prays that his outside and inside coordinate, ${ }^{27}$ in [8] the Palinode states that philosophy means acting (publicly) as the mind decides (privately).

\section{A PROTREPTIC TO PHILOSOPHY}

At the close of the Palinode, Socrates wishes that Phaedrus would turn to philosophy. $\mathrm{He}$ prays to Erôs, using 'philosophy'-group words twice in close succession:

[9] Blaming Lysias as father of the [first] speech, stop him from [making] such speeches, and turn him to philosophy, just as Polemarchus, his brother, has been turned. (257b2-4)

[10] [Do this] so that this lover of him no longer wavers as he does now, but wholly toward love accompanied by philosophical speeches he may make his life. (257b4$-6)$

We may not know exactly why Lysias' speech-making does not count as philosophical; Socrates obscures his critique of Lysias' speech to the unloved (234e5-235a8). But Socrates says that Polemarchus has turned toward philosophy. The Phaedrus tells us nothing else about Polemarchus; but in the Republic, we see that Polemarchus engages Socrates well in conversation. ${ }^{28}$ Polemarchus opens the Republic by having his slave restrain Socrates; Socrates learns that he wishes to force him into joining him and others in a discussion at his house followed by the observation of some new races (327a1-328a10). He interrupts Socrates to defend his father once Cephalus fails to give a consistent answer to Socrates' questions about justice, on the grounds that Simonides supports Cephalus' contention. For several pages he supports Simonides' view, graciously modifying it when Socrates shows his earlier interpretations to be untenable. As he fails to support even these modifications, he says that he would gladly join Socrates in battle against those who believe justice means harming one's enemies (331d3-336a8). Some books later, Polemarchus and Adeimantus whisper to each other. We learn that they were complaining that Socrates did not explain how the community of wives and children, the idea for which follows from the view that friends hold possessions in common, should be manifest in the city he describes (449a7-450a1). This evidence does not support anything about Polemarchus' concern for the really real, or an acceptance of universal forms, or a use of certain conversational methods. It shows only that Polemarchus loves conversation with Socrates, cares about the most plausible views of justice, graciously accepts Socrates' questions and refutations, and is curious about the practical details of this theoretical model. Philosophy is something concerned with valuable conversations.

Passage [10] echoes, as we noted before, [5]. Phaedrus sees value in both the life Lysias models and the life Socrates describes. As Socrates describes it here, the life he describes is the life not of 'philosophy' but of 'love accompanied by philosophical speeches'. This suggests that philosophy describes a kind of conversation with a beloved. The Palinode depicts just one beloved, the one to whom the lover is madly attuned. From the examples of Socrates with Polemarchus and with Phaedrus, though, we get the sense that a beloved can be any close friend in whom a 'lover' - an avid friend takes great interest. From the conversations with Polemarchus depicted in the Republic, we see that such conversations will be those 
that press a person to express what he finds most valuable and true, and then to undergo testing of those views he expresses.

Socrates' exhortation to philosophy continues even after the Palinode. He turns from his explicit concern with speech competition and the nature of love to the nature of good speaking and writing. Perhaps because he intends to speak with less rhetorical brilliance, he tells Phaedrus that their continued conversations remain beloved by the divine and in particular by the Muses.

[11] The cicadas report to the most senior Muses, Calliope and Ourania, who among humans spends time in philosophy

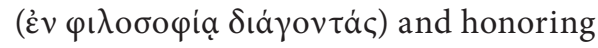

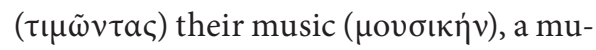

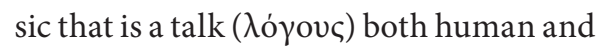
divine and that has the most beautiful

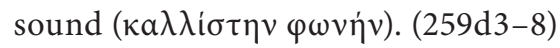

Philosophy honors the Muses' sonorous talk. This talk is both human and divine; as we have learned before, at the level of the concern for virtue, these coincide. Socrates treats what he has said as reasons that they continue to talk ( $\lambda \varepsilon \kappa \tau \dot{\varepsilon} \mathrm{\delta} v)$. This suggests that philosophy honors the gods by mirroring their speech, on the human - though still aspirationally divine - plane.

\section{PHILOSOPHIZING AND SPEAKING ADEQUATELY}

The presumably philosophical conversation to which Socrates encourages Phaedrus' commitment proceeds, for the remainder of the dialogue, as a meandering inquiry into the nature of speaking well. A good speaker needs only to know what an audience finds persua- sive, Phaedrus tells Socrates (260a1-4). Socrates shows in return that Phaedrus does not really believe this (260b1-d1). But in showing him this, Socrates worries that he has spoken too harshly against the partisan of rhetoric (260d3-

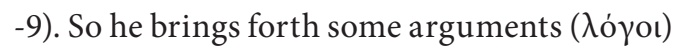
to represent a more nuanced position. He addresses those logoi:

[12] Come to us, noble creatures, and persuade our beautiful-child Phaedrus that unless he philosophizes adequately

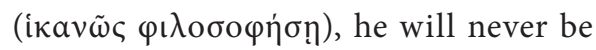

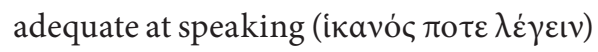
about anything.

Philosophizing makes one a good orator. It is at first hard to know how this is so. The logoi go on to claim that perfect deception requires perfect knowledge about everything (261d10$262 \mathrm{c3}$ ). So it would seem that philosophy is knowledge of the details of everything in the world, so that, as the logoi say, one may know how exactly everything differs. It turns out that this argument is itself deceptive, because it is invalid, and deliberately so. ${ }^{29}$ Furthermore, nothing in the previous eleven uses of 'philosophy'-group words has suggested that philosophizing involves becoming omniscient. Indeed, the few instances relating philosophy to contact with the really real suggest distancing oneself from the bulk of things one could possibly know to focus on the most fundamental aspects of the world. Even more tellingly, the conversation between Socrates and Phaedrus that follows, which seems to epitomize good discussion - Socrates, after all, persuades Phaedrus - does not, as far as I can tell, require Socrates to know everything. So the logoi, not surprisingly given their name, '[mere] arguments', do not satisfactorily link philosophy and omniscience. 
Yet the logoi's invalid, unprecedented, and incongruous discussion of philosophy here may have a positive lesson. It seems likely that both Phaedrus and we are to remember that philosophizing is something quite different than knowing the details of everything in the world (a similar lesson is given by the Platonic Rival Lovers). It seems perhaps a response to the fact that we do not know all those details. As philosophers we are instead to maintain a critical consciousness in conversation, to make sure to say what we really believe, and to ask questions when our interlocutor's remarks become unclear or too abstract.

\section{BEING WISE VS. BEING A PHILOSOPHER}

In the opening of this paper, I quoted one of Socrates' closing remarks of the dialogue. It is the passage that appears to make an etymological play on the word philosophos.

[13] Regarding whoever composes spee-

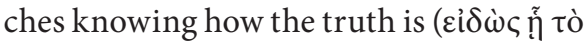

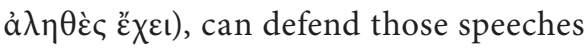
( $\varepsilon \chi \omega \nu \beta \circ \eta \theta \varepsilon \tilde{\varepsilon} v)$, and can show that they are of little worth ( $\lambda \dot{\varepsilon} \gamma \omega v$ av̉ंò $\delta v v a \tau o ̀ \varsigma$

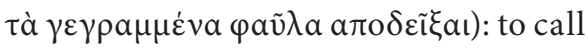

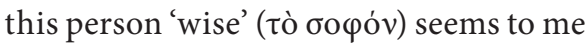
to be grand and appropriate for god alone; but either 'philosopher' or something like that would be more fitting for him and be more in tune. (278d)

The second and third criteria for philosopher-hood are simple enough. Defending a view is a central part of any productive conversation, especially those about one's possession of virtues. The Platonic dialogues show little else besides conversations containing defenses of such morally-relevant positions. And showing that one's composed words are of little value requires only the awareness and self-awareness described in the Apology, that the world is much more complicated than mere mortals can apprehend. This awareness comes especially through conversation, the reciprocal testing of one's and another's views.

It is the first criterion on which controversy rests. What truth must a philosophical speaker know? It cannot be the truth of the really real, since only gods have this state of wisdom, and philosophers differ from the gods. Nor was there ever a satisfactory argument in favor of the philosopher being omniscient, knowledgeable about absolutely anything a person might talk about. It is not obvious what remains. In fact I take it as a deliberate aporia in the dialogue, what the good speaker should know. This aporia follows Socrates everywhere; it is never obvious what he knows - besides his own ignorance, perhaps, and ta erôtika - such that his conversations and life go the way they do. What seems more obvious is that a philosophical speaker would know, besides the ways both to defend a speech and to abandon a speech, about what to make a speech. One should talk about what really matters, what would really honor the gods (277d10-278b4). For the philosopher, knowing the truth may amount to knowing truly what to talk about.

Socrates does not make much of the fact that this is the 'philosopher's' activity. Some other name would work just as well. ${ }^{30}$ The etymological connection implied between sophon and philosophon is playful, but provides little information. The philosopher may have some relationship to the wise person (sophon) or to wisdom (sophia), but the prefix phil- does not establish the tenor of that relationship with any determinacy. 


\section{ISOCRATES' PHILOSOPHIA}

We find the final use of the dialogue's freighted term, philosophia, in Socrates' closing remarks about Isocrates, cited at the beginning of this paper. Here I quote the entire passage. Socrates has just told Phaedrus to relate the above results concerning philosophy to Lysias.

[14] Phaedrus: And you - what? How will you proceed? For we must not at all leave aside your companion.

Socrates: Who is this?

P.: Isocrates the beautiful; what will you report to him, Socrates? What will we call him?

S.: Isocrates is still young, Phaedrus; but what I prophecy for him, I am willing to say.

P.: What is it?

S.: He seems to me better in terms of speeches when compared to Lysias, as far as his nature is concerned; and still more, to be more nobly blended in his character, so that it would be worth no amazement were, as he grows older, the difference, in the speeches which he attempts now, between him and those who have so far undertaken speech-writing, to become greater than that between man and boys; and yet more again, if he were to be unsatisfied with that, and some diviner impulse led him to greater things; for there is by nature some philosophy in the mind of that man. (tr. after Rowe)

This is Plato's sole explicit reference to Isocrates in his dialogues. ${ }^{31}$ What explains Plato's silence everywhere else is hard to say. But this paper is not really about Isocrates; it is about the nature of the philosophy Socrates exhorts
Phaedrus to take up, and whether we are to take Socrates to mean strongly opposed things by 'philosophy'.

What seems clear is that up to this point, Socrates has not distinguished between multiple distinct types of philosophy or philosophers. He has done quite the opposite, observing that many types of people not explicitly named 'philosophers' share in the essential features of philosophy. There are no grounds for the reader to assume, then, that Socrates here in [14] refers to a special, heretofore unmentioned 'philosophy'. It is in fact easy to understand Socrates' point about Isocrates while assuming that 'philosophy' means here what it has meant throughout the dialogue. Socrates could be saying that Isocrates knows what he should be talking about, the education and wellbeing of people; knows how to defend his positions, giving arguments of a varied nature; and knows the relative poverty of his wisdom, presuming a modesty of pedagogical power. ${ }^{32}$ It might even be possible that young Isocrates seeks, to some degree, to know about the nature of justice and self-control and knowledge. Saying all this is completely compatible with Plato's putative belief that Isocrates, in his mature age, has lost some of these traits, despite holding onto the word 'philosophy' in his practice. ${ }^{33}$ Perhaps Plato's disappointment with Isocrates has even more pathos given his belief that Socrates would have approved of the young Isocrates. The similarity in the names of Socrates and Isocrates is probably not lost on Plato (cf. Statesman 258a1), and so too similarities, and dissimilarities, in their intellectual practices. 


\section{CONCLUSION}

In this study of 'philosophy'-group words in the Phaedrus, we have found that there is no obvious bifurcations in the term's use, where some instances would have a 'conventional' or 'rhetorical' meaning and others would have a 'technical' or 'Platonic' meaning. All uses are connected to conversations concerned to diagnose and improve a person's level of virtue. On some occasions, Socrates or his Palinode emphasizes the connection between virtue and knowledge. On other occasions, the emphasis is on the connection between virtue and self control. In either cases, philosophy is the critical attitude and set of practices dedicated to developing and helping others develop the good life. There is no reason to think that Socrates could not see young Isocrates as characterized by such an attitude and set of practices, nor even to think that Isocrates himself did not believe that his own teaching wholly embodied these attitudes and practices. What Socrates encourages Phaedrus to pursue is a life of engaged and reflective conversation typified by the conversation depicted in the Phaedrus. ${ }^{34}$

\section{BIBLIOGRAPHY}

Belfiore 2012: E. Belfiore, Socrates' Daimonic Art: Love for Wisdom in Four Platonic Dialogues. Cambridge University Press, Cambridge 2012.

Betegh 2009: G. Betegh, 'Tale, Theology and Teleology in the Phaedo', in C. Partenie (ed.), Plato's Myths, Cambridge University Press, Cambridge 2009, 77-100.

Brown - Coulter 1971: M. Brown - J. Coulter, 'The Middle Speech of Plato's Phaedrus', «Journal of the History of Philosophy» 9 (1971), 405-423.

Burger 1980: R. Burger, Plato's Phaedrus: A Defense of a Philosophic Art of Writing. University of Alabama Press, Tuscaloosa 1980.
Cahn 1989: M. Cahn, 'Reading Rhetoric Rhetorically: Isocrates and the Marketing of Insight', «Rhetorica» 7 (1989), 121-144.

Clay 1979: D. Clay, 'Socrates' Prayer to Pan', in G.W. Bowersock, W. Burkert, and M.C.J. Putnam (ed.), Arktouros: Hellenic Studies Presented to B. M. W. Knox. De Gruyter, Berlin 1979, 345-353.

Collins 2015: J.H. Collins, Exhortations to Philosophy: The Protreptics of Plato, Isocrates, and Aristotle, Oxford University Press, Oxford 2015.

Cooper 2004: J.M. Cooper, 'Plato, Isocrates, and Cicero on the Independence of Oratory from Philosophy', in Knowledge, Nature, and the Good, Princeton University Press, Princeton 2004, 65-80.

Coulter 1967: J.A. Coulter, 'Phaedrus 179a: The Praise of Isocrates', Greek, Roman and Byzantine Studies 8 (1967), 225-236.

De Vries 1954: G.J. De Vries, 'Isocrates' Reaction to the Phaedrus', «Mnemosyne» 6 (1954), 39-45.

De Vries 1969: G.J. De Vries, A Commentary on the Phaedrus of Plato. Hakkert, Amsterdam 1969.

De Vries 1971: G.J. De Vries, 'Isocrates in the Phaedrus: A Reply', «Mnemosyne» 24 (1971): 387-390.

Dusanic 1999: S. Dusanic, 'Isocrates, the Chian Intellectuals, and the Political Context of the Euthydemus', «Journal of Hellenic Studies» 119 (1999), 1-16.

Freeman 1938: K. Freeman, 'Portrait of a Millionaire Callias Son of Hipponicus', «Greece and Rome» 8 (1938), 20-35.

Gifford 2001: M. Gifford, 'Dramatic Dialectic in Republic Book 1', «Oxford Studies in Ancient Philosophy» 20 (2001), 35-106.

Gill 2012: M.L. Gill, Philosophos: Plato's Missing Dialogue. Oxford University Press, Oxford 2012.

Goggin - Long 1993: M.D. Goggin - E. Long, 'A Tincture of Philosophy, a Tincture of Hope: The Portrayal of Isocrates in Plato's Phaedrus', «Rhetoric Review» 11 (1993): 301-324.

Gomme 1945: A.W. Gomme, A Historical Commentary on Thucydides, Vol 1: Introduction and Commentary on Book 1, Clarendon Press, Oxford 1945.

Griswold 1986: C. Griswold, Self-Knowledge in Plato's Phaedrus, Yale University Press, New Haven 1986.

Hadot 2004: P. Hadot, What Is Ancient Philosophy? Harvard University Press, Cambridge, MA 2004.

Howland 2004: J. Howland, 'Plato's Reply to Lysias: Republic 1 and 2 and Against Eratosthenes', 
«American Journal of Philology» 125 (2004), 179-208.

Howland 1937: R.L. Howland, 'The Attack on Isocrates in the Phaedrus', "Classical Quarterly» 31 (1937), 151-159.

Johnson 1959: R. Johnson, 'Isocrates' Methods of Teaching', «American Journal of Philology» 80 (1959), 25-36.

Labriola 2014: D. Labriola, 'On Plato’s Conception of Philosophy in the Republic and Certain Post-Republic Dialogues', Ph.D Dissertation. St. Andrews 2014.

Laks 2002: A. Laks, 'Philosophes Présocratiques: Remarques sur la construction d'une catégorie de l'historigraphie philosophique', in A. Laks and C. Louguet (ed.), Qu'est-ce que la Philosophie présocratique?, Presses Universitaires du Septentrion, Villeneuve-D’Ascq 2002, 17-38.

Livingstone 2007: N. Livingstone, 'Writing Politics: Isocrates' Rhetoric of Philosophy', «Rhetorica» 25 (2007), 15-34.

McAdon 2004: B. McAdon, 'Plato's Denunciation of Rhetoric in the Phaedrus', «Rhetoric Review» 23 (2004), 21-39.

McCoy 2009: M.B. McCoy, 'Alcidamas, Isocrates, and Plato on Speech, Writing, and Philosophical Rhetoric', «Ancient Philosophy» 29 (2009), 45-66.

Moore 2013: C. Moore, 'Deception and Knowledge in Plato's Phaedrus', «Ancient Philosophy» 33 (2013), 97-110.

Moore 2014: C. Moore, 'Socrates Psychagogos', In A. Stavru and F. de Luisa (ed.), Socratica III, Akademie Verlag, Berlin 2014, 41-55.

Moore 2016: C. Moore, 'Spartan philosophy and Sage wisdom in Plato's Protagoras', «Epochê» 30 (2016).

Most 1994: G. Most, 'Simonides' Ode to Scopas in Context', in I.F. de Jong and J.P. Sullivan (ed.), Modern Critical Theory and Classical Literature, Brill, Leiden 1994, 127-154.

Munn 2000: M. Munn, The School of History: Athens in the Age of Socrates, University of California Press, Berkeley 2000.

Murphy 2013: D. Murphy, 'Isocrates and the Dialogue', «Classical World» 106 (2013), 311-353.

Nehamas 1990: A. Nehamas, 'Eristic, Antilogic, Sophistic, Dialectic: Plato's Demarcation of Philosophy from Sophistry', «History of Philosophy Quarterly» 7 (1990), 3-16.
Nightingale 1995: A.W. Nightingale, Genres in Dialogue: Plato and the Construct of Philosophy, Cambridge University Press, Cambridge 1995.

Nightingale 2004: A.W. Nightingale, Spectacles of Truth in Classical Greek Philosophy: Theoria in Its Cultural Context, Cambridge University Press, Cambridge 2004.

Page 1990: C. Page, 'The Unjust Treatment of Polemarchus', «History of Philosophy Quarterly» 7 (1990), 243-267.

Peterson 2011: S. Peterson, Socrates and Philosophy in the Dialogues of Plato, Cambridge University Press, Cambridge 2011.

Poulakos 2001: T. Poulakis, 'Isocrates' Use of Doxa', «Philosophy and Rhetoric» 34 (2001), 61-78.

Rashed and Hoffmann 2008: M. Rashed and P. Hoffmann, 'Platon, Phèdre, 249b8-c1: Les Enjeux D’une Faute D'onciales', «Revue des Études Grecques» 121 (2008), 43-54.

Rowe 1986: C.J. Rowe, Plato: Phaedrus, Aris \& Phillips, Warminster 1986.

Rusten 1985: J.S. Rustin, 'Two Lives or Three: Pericles on the Athenian Character (Thucydides 2.40.1-2)', «Classical Quarterly» 35 (1985), 14-19.

Ryan 2012: P. Ryan, Plato's Phaedrus: A Commentary for Greek Readers, University of Oklahoma Press, Norman 2012.

Timmerman 1998: D.M. Timmerman, 'Isocrates' Competing Conceptualization of Philosophy', «Philosophy \& Rhetoric» 31 (1998), 145-159.

Wareh 2012: T. Wareh, The Theory and Practice of Life: Isocrates and the Philosophers, Center for Hellenic Studies, Washington 2012.

Werner 2012: D.S. Werner, Myth and Philosophy in Plato's Phaedrus, Cambridge University Press, Cambridge 2012.

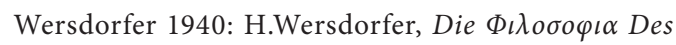
Isokrates Im Spiegel Ihrer Terminologie, O. Harrassowitz, Leipzig 1940.

Wilcox 1943: S.Wilcox, 'Criticisms of Isocrates and

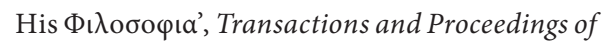
the American Philological Association 74 (1943), 113-133.

Wolfsdorf 1998: D. Wolfsdorf, 'The Historical Reader of Plato's Protagoras', «Classical Quarterly» 48 (1998), 126-133.

Yunis 2011: H. Yunis, Plato: Phaedrus, Cambridge University Press, Cambridge 2011. 


\section{NOTES}

1 Recent studies revisiting "philosophy" in so-called "later" dialogues are found in Gill 2012 and Labriola 2014; see also Peterson 2011.

2 All translations by the author unless noted. 3 Goggin and Long 1993 give the neat if overly-

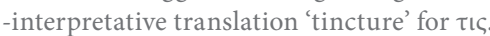
4 For Isocrates' view of philosophia see Wersdörfer 1940; Wilcox 1943; Cahn 1989, 124-137; Nightingale 1995, 26-41; Timmerman 1998; Poulakos 2001; Livingstone 2007; McCoy 2009, 53-58; Wareh 2012, 30-54; Murphy 2013; Collins 2015, 171-181.

5 To the references in the above note add $\mathrm{Ne}$ hamas 1990; Nightingale 2004, 14-35; Cooper 2004. 6 De Vries 1969 ad 279a9; see also his 1953, 40-41, and 1971, 388.

7 Yunis 2011 ad 279a8-b2; similar views about two opposed senses of philosophia are held by Brown and Coulter 1971, 411-414, and Griswold 1986, 286n18. McAdon 2004, 32-35 supports his view that Isocrates' view of philosophy is different from Plato's in the Phaedrus by appeal only to Plato's uses of the term 'philosophy' found outside the Phaedrus.

8 Werner 2012, 230n162; see also 120n40 and 228-229.

$9 \quad$ For the Phaedrus as Plato's contest with Isocrates, see also Howland 1937; Coulter 1967; McAdon 2004; and more mildly in Burger 1980, 115-126; Goggin and Long 1993; McCoy 2009.

10 Still, knowing this attitude may advance our understanding of fourth-century philosophy; see Wareh 2012, 55-75.

11 The Euthydemus includes many protreptic speeches to philosophy; see $275 \mathrm{a} 2,282 \mathrm{~d} 2,288 \mathrm{~d}$. The $\mathrm{Al}$ cibiades and Clitophon, dialogues deeply concerned with protreptic speeches to justice, do not use the 'philosophy'-word group.

12 I note that 'philosophy' is the word Socrates as narrator of the historical conversation uses; he does not say what word he in fact used in 429. It is unimportant to my argument.

13 On Callias' profligate commitment to sophists, ideas, and Protagoras' ideas, see Apol. 20a3-c3, Tht. 165a1-2, Xen. Symp. 1.4-6, and Freeman 1938; Wolfsdorf 1998, 127-129.

14 That the Spartans have the most sophistai suggests, further, they have the most people characterized by knowledge of wisdom (312c8), nourishing souls on mathemata (313c), or teaching people to become better (316d-317c).

15 The two other uses of 'philosophy' group words in the dialogue are in this passage, glossing the uses already mentioned: 342e6, 343b4. See Most 1994 and Moore 2016 for further discussion.

16 Brown and Coulter 1971 argue that this speech imitates ones Isocrates, or at least his ilk, would write.
$17 \quad$ Yunis 2011 ad 239b4. De Vries ad 239b4 says that the term is used here 'not in its Platonic meaning, but used as the term was generally used in the IV century BC'; Rowe 1986 ad 239b3-4 tempers De Vries' position but still suggests that Socrates has in mind 'philosophy in the narrow sense' (although it is unclear how this is 'narrower' than any other sense).

18 The lives companion to philosophers are frequently ignored, as most recently in Werner 2012, 119.

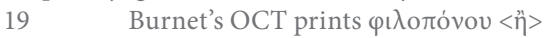
$\gamma v \mu v a \sigma \tau \iota \kappa \tilde{\omega} v$ (conjectured by Badham). This would make three people: the belabored man, the gymnastic man, and the man of healing.

20 Yunis 2011, 114-115 conjectures an interesting account of the groupings.

21 On the date of Thucydides' authorship, Munn 2000, 12; on the dramatic date of the Phaedrus, Yunis 2011, 7-8.

22 Gomme 1945 ad loc does not take the discussion of political preparation to gloss the meaning of 'philosophize', but instead as a parallel - 'the comparison is with other Greeks, Boeotians and Peloponnesians, who would think a love of learning to be as inconsistent with courage as political discussion with decisiveness of action' - but this seems a misreading of Thucydides' logic. Hadot 2004, 16 claims that Pericles treated his audience as 'proud of [their] intellectual activity and the interest in science and culture which flourished in their city'; Laks 2002,30 , takes philosophizing to be equivalent to being attracted by the fine arts and literature. Rusten 1985 is only half-right when he says that 'it is no longer necessary

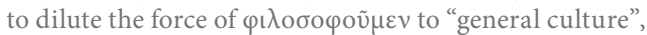
since it need not apply equally to every Athenian', and he loses specificity when he holds that 'on an individual

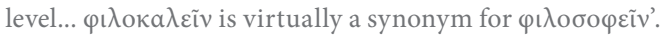
23 Betegh 2009 argues for the philosophical importance of Socrates' understanding of Aesop.

24 Cf. Belfiore 2012.

25 See de Vries 1969 ad 249b7-c1; Hoffmann and Rashed 2008; and Yunis 2011 ad 249b6-c1, on the conjectural emendations to this text.

26 De Vries 1969 ad loc reads kata eidos as 'in generic terms'. Yunis 2011 ad loc translates it as 'with respect to form' and says that " what is said with respect to form" is a discourse conducted on a higher, more abstract level than concrete instances or individual perceptions, as is evident in the use of "form" ( $\varepsilon \tilde{\varepsilon} \delta \circ \varsigma$, i $\delta \dot{\varepsilon} \alpha)$ in the account of dialectical reasoning later in the dialogue (265d1-266b2)'. Ryan ad 249b6-cl gives 'according to class (or type)', and implies, I think, that understanding a thing said according to class means putting all instances of that thing under a single concept and giving it a single name. Rowe 1986 ad $249 \mathrm{~b} 7$ combines the suggestions I have already quoted: "literally, "something which is said in accordance with/in relation to eidos" - eidos in the sense of "class"..., perhaps, rather than "Form"; or else both.' 27 On this closing prayer see Clay 1979; Griswold 1986, 226-229; Yunis 2011, 246-249; Werner 2012, 230-235. 
28 On Polemarchus' character, see Page 1990; see Gifford 2001 and Howland 2004 on the historical events involving Polemarchus alluded to in Republic Book 1.

$29 \quad$ Moore 2013 and Moore 2014.

30 Yunis 2011 ad loc gives a list of alternative names culled from the dialogue.

31 Many scholars also read an allusion to Isocrates in Euthydemus 304d4-306d1; see Dusanic 1999. 32 Johnson 1959 attempts a reconstruction of Isocrates' thoughtful pedagogical method.

33 Werner 2012, 227-230 and n158, by contrast, thinks, for reasons I cannot intuit, that 'Plato was angered

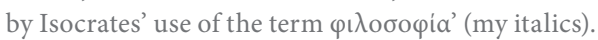

$34 \quad$ I presented a short version of this paper at Lehigh University (October 2013). 